ARCTIC

\title{
Parental Care and Adult Aggression toward Juvenile Snowshoe Hares
}

\author{
R.P. GRAF ${ }^{1,2}$ and A.R.E. SINCLAIR ${ }^{2}$
}

\author{
(Received 21 July 1986; accepted in revised form 12 March 1987)
}

\begin{abstract}
The early life of the snowshoe hare was studied through observations and experiments involving penned and wild hares. Parental care was limited to the adult female. Her care extended only to lactation and possibly to some guarding of her offspring. The leverets gathered at the birth/nursing site 1-2 hours after sunset and suckled immediately upon the arrival of the female for 2-5 minutes. The leverets born in the pens gained $17.1 \mathrm{~g}$ per day for the first 60 days of life.

Weaned juveniles caught in the wild were introduced into a pen containing resident adults and juveniles. All 30 introduced juveniles were involved in interactions with residents, both adults and juveniles. The introduced juveniles were involved in and were the losers in more agonistic interactions than were resident juveniles. Similar adult/juvenile and juvenile/juvenile interactions were observed in an unmanipulated wild population of hares, although the residential status of many of the participants was unknown. We concluded that aggression from resident adults and juveniles could lead to spacing behaviour and might therefore affect juvenile recruitment.
\end{abstract}

Key words: Lepus americanus, snowshoe hare, spacing behaviour, dispersal, aggression, lactation

RÉSUMÉ. On a étudié les premiers mois de la vie du lièvre d'Amérique en faisant des observations et des expériences sur des lièvres parqués dans des enclos et sur d'autres vivant à l'état sauvage. La femelle adulte était seule à s'occuper des petits, et les soins qu'elle leur donnait se limitaient à la tétée et peut-être à une certaine surveillance. Les levrauts commençaient à se rassembler au lieu de leur naissance et des tétées de une à deux heures après le coucher du soleil, et ils tétaient de 2 a $5 \mathrm{mn}$, dès l'arrivée de la femelle. Les levrauts nés dans les enclos gagnaient $17,1 \mathrm{~g}$ quotidiennement pendant leurs 60 premiers jours.

Des jeunes sevrés et capturés dans la nature ont été introduits dans un enclos où se trouvaient déjà des adultes et des petits. Les 30 jeunes introduits ont tous été impliqués dans des interactions avec les résidents aussi bien les adultes que les petits. Les jeunes introduits ont été impliqués dans plus d'interactions agressives que les petits déjà dans l'enclos, et ils en sont sortis plus souvent perdants. Sans toutefois connaitre le statut d'appartenance de beaucoup des membres, on a observé des interactions similaires entre les adultes et les jeunes et entre les jeunes eux-mêmes dans une population de lièvres vivant à l'état sauvage et $n$ 'ayant pas été en contact avec l'homme. On conclut que l'agression des adultes et des petits du groupe peut conduire à un comportement de distanciation et pourrait donc affecter le taux de reproduction.

Mots clés: Lepus Americanus, lièvre d'Amérique, comportement de distanciation, éparpillement, agression, lactation

Traduit pour le journal par Nésida Loyer.

\section{INTRODUCTION}

There is little information available on the early life history of snowshoe hares, Lepus americanus. Severaid (1942) provides leveret growth rates and some observations on parental care but presents little information on juvenile/adult or juvenile/juvenile social interactions. Rongstad and Tester (1971), using data from two radio-tagged female snowshoe hares, showed that lactating females visited their litters only once each night and suggested that females wean their litters by not returning to nurse. Boutin (1979) suggested that weaned juveniles weighing less than $500 \mathrm{~g}$ move to areas of low adult density.

Snowshoe hares, like other cyclic species, exhibit major changes in juvenile survival rates that follow the trend of population numbers (Krebs and Myers, 1974; Keith and Windberg, 1978; Krebs et al., 1986). Keith and Windberg (1978) also found that juvenile survival was the demographic factor that correlated best with the rate of increase in hare population through the cycle. They hypothesized that the lower juvenile survival, which precipitates the decline in numbers, is a result of less food being available in the fall and early winter. Alternative hypotheses, such as behavioural stress and spacing behaviour, as possible causes of the cycle have not been considered (Christian and Davies, 1964; Chitty, 1960; Krebs and Myers, 1974). If spacing behaviour is important in the hare cycle, then it should be effective during that period of the life stage correlated best with changes in density, namely, the juvenile stage.

This paper provides, first, information from penned hares on parental care, nursing behaviour and growth rates. Second, we examine what happens to weaned juveniles when they begin expanding their ranges and encountering unfamiliar adults and juveniles. We studied this by introducing wild juveniles into large pens that already contained resident adult and juvenile hares. We predicted that introduced (non-resident) juveniles would be involved in and would lose more agonistic interactions with resident adults than would resident juveniles. Juveniles were then observed in the wild to see whether similar types of interactions occurred in wild hares as had occurred during the pen experiments.

\section{METHODS}

This study was conducted near the Kluane Lake Research Station of the Arctic Institute of North America, southwestern Yukon, Canada. The vegetation is dominated by white spruce (Picea glauca) but has a varied understory of willows (Salix spp.), buffalo berry (Shepherdia canadensis) and many herb species. Douglas (1974) has described the vegetation in detail.

To observe captive animals, two pens $30 \mathrm{~m} \times 30 \mathrm{~m}$ were constructed in 1979 using chain link fencing. A plywood blind with Plexiglas windows was set $1.5 \mathrm{~m}$ above ground level for each pen. Vegetation inside the pens was selectively trimmed to facilitate observation. An electrified wire $50 \mathrm{~cm}$ above ground level was placed around both compounds to discourage terrestrial predators. In 1980 one pen was partially covered with fish netting to discourage predation by goshawks (Accipiter gentilis) and great horned owls (Bubo virginianus).

\footnotetext{
'Present address: Department of Renewable Resources, Government of the Northwest Territories, Yellowknife, Northwest Territories, Canada XIA 2L9

${ }^{2}$ Department of Zoology, University of British Columbia, Vancouver, British Columbia, Canada V6'T 1W5

(C) The Arctic Institute of North America
} 
Hares inside the pens were provided with commercial rabbit chow (16-20\% protein) and water ad libitum, and willow stems were added every 2-3 days to supplement the chow. Although hares accepted the chow quickly, they preferred the willow leaves, twigs and bark (Graf, 1981).

As soon as young hares were found in the pens, they were weighed, sexed and ear-tagged. Thereafter, the leverets were caught weekly by using traps or nets. Once they had reached a weight of $150 \mathrm{~g}$, a coloured plastic ear disc was attached for individual identification.

Resident juveniles were those born in the pen that summer. Data on agonistic interactions between resident hares were gathered both during the introduction of wild juveniles (140 hours) and at other times throughout the two summers when no manipulations to the penned hares had occurred (44 hours).

Wild juveniles were live-trapped and marked with plastic disc ear tags. They were held individually in smaller holding pens ( 2 $\mathrm{m} \times 6 \mathrm{~m}$ ) before being introduced into one of the larger pens that contained resident hares. Ten wild juveniles were introduced during the summer of 1979 and 20 in 1980 . The 30 wild juveniles were made up of 15 females and 15 males, ranging in weight from 520 to $1090 \mathrm{~g}$, with a mean of $789 \mathrm{~g}$ (males $=782$ $\mathrm{g}$; females $=796 \mathrm{~g}$ ). These weights indicate that the ages of the introduced juveniles ranged from 28 to 60 days, with a mean age of 45 days. Snowshoe hares are weaned at 25-28 days (Severaid, 1942; this study). Reactions of the resident and non-resident hares were observed for 2-3 hours immediately after the introduction in the evening and for 2-3 hours more the following morning. The introduced hare was then recaptured and released into the wild. The resident population consisted of 3-5 adults of both sexes and varying numbers of leverets born in the pen. The weights of the resident leverets changed throughout the course of the experiment.

Wild juvenile hares were observed during the summer of 1980. We are able to differentiate between leverets from the first and second litters by their body size until late in the summer.

\section{RESULTS}

\section{Nursing Behaviour and Parental Care}

The 12 leverets that made up the three litters in the pen in 1980 were approximately three weeks old and weighed about $300 \mathrm{~g}$ each when observations were made on their nursing behaviour. Hares became active in the late evening. At approximately midnight the leverets ceased their other activities and moved to three different locations in the pen. The leverets at any one location then huddled together, at times grooming each other. Within the next 10-15 minutes a female approached a group and sat down on her hindquarters with forelegs straight, dog-like. The leverets quickly ran to her and began suckling. The female remained sitting on her hindquarters and licked the young as they fed. Nursing lasted 2-5 minutes and was terminated when the female moved away. Nursing of these litters was observed on three consecutive nights, and the same leverets were usually found at the same location, with the same female. It was assumed that these three groups were the three litters, but one juvenile did suckle from two different females. On another occasion one complete litter suckled from two females within 10 minutes; the non-parent female had stopped quite close to the awaiting litter, and as one of her own young began feeding, the other litter, containing five leverets, ran in and began suckling.
Five minutes later the parent doe approached and the same litter suckled once again. These exceptions indicated the lactating female may not identify the leverets before allowing them to feed. Broekhuizen and Maaskamp (1980) reported similar mixing of litters occurring in the European hare, L. europaeus.

Apart from suckling, female snowshoe hares provided little further parental investment (in the sense of Trivers, 1972), as they had little to do with the leverets at any other time. During daylight hours leverets usually remained under cover, as did adults. However, unlike adults, who remained solitary, leverets often rested in groups of up to six young. Members of these groups were not always from the same litter, and groups sometimes contained individuals from all three litters.

One type of parental investment found in many species is the guarding of offspring against predators. Leverets sometimes screamed when we handled them, and on several such occasions the female parent approached to within $2 \mathrm{~m}$. Other hares in the pens, both males and females, reacted to such screams as well, by assuming an alert posture (standing upright on the hind legs) or by moving toward the distressed leveret. Such reaction by adult hares to the distress call of a leveret suggests that adult hares were attempting either to protect their young or to identify the predator. On one occasion we observed a grey jay, Perisorcus canadensis, pecking a live one-day-old leveret while the female excitedly hopped around the bird but never physically attempted to prevent the death of its offspring by attacking the smaller predator. The parent hare was unable to prevent the bird picking up the struggling leveret and carrying it away.

\section{Litter Size and Juvenile Growth Rates}

Twenty litters of leverets were produced by the penned females in the two years. Females did not prepare a structured or fur-lined nest, but merely clumped the young together under some cover in a ground depression at the base of a tree or under a windfall. We were able to determine if a litter was born recently, as the precocial, fully furred leverets had damp fur for up to one hour after birth (Severaid, 1942). Parturition occurred during both day and night.

The gestation period for $L$. americanus is 36 days (Severaid, 1942). At birth the young weighed an average of $59 \mathrm{~g}(\mathrm{~N}=13$; range 50-75). Age (x) and weight (y) showed a strong linear relationship over the first 60 days $(r=0.985, n=71, y=17.12 x$ +3.71 ). Leverets gained an average of $17.1 \mathrm{~g}$ per day from birth to approximately 60 days of age. If the growth rate found in the pens applies to wild hares in the Yukon, leverets weaned at 25-28 days weighed 425-480 g. Leverets were first observed feeding on vegetation and rabbit chow at 7 days of age.

\section{Interactions with Introduced Juveniles}

Non-resident juveniles, upon introduction to the pen, moved about the area investigating their new surroundings. Agonistic interactions between resident hares and the introduced juvenile often occurred during this investigation, when either residents or introduced animals approached and sniffed each other. As in resident/resident encounters, interactions occurred over access to food, water or resting spots and when meeting along welltravelled pathways.

All 30 of the introduced juveniles were involved in aggressive interactions with resident hares. Non-resident juveniles were involved in more interactions per hour than were resident juveniles (Table 1: Mann-WhitneyU-test, $P<0.001$ ). The hourly 
TABLE 1. Number of interactions participated in and number won by introduced and resident juveniles ${ }^{1}$

\begin{tabular}{lcccc}
\hline Hare type & $\begin{array}{c}\text { Number of } \\
\text { interactions }\end{array}$ & $\begin{array}{c}\text { Number of } \\
\text { hare hours }\end{array}$ & $\begin{array}{c}\text { Interaction/ } \\
\text { hare hour }\end{array}$ & Percent won $^{3}$ \\
\hline Introduced & 401 & 140 & 2.86 & 10.8 \\
Residents & 296 & 681 & 0.43 & 57.4 \\
\hline \hline
\end{tabular}

${ }^{1}$ Introduced juveniles were involved in more interactions per hour but won a lower percentage of interactions than did resident juveniles.

${ }^{2}$ Number of hare hours $=$ (number of hours of observations) $\times$ (number of juveniles of that classification present, i.e., introduced or resident).

${ }^{3}$ Percent won $=$ (number of interactions won/total number of interactions participated in) $\times 100$.

interaction rate for resident juveniles was calculated by dividing the total number of interactions involving a juvenile by the number of observation hours and then dividing by the number of juveniles present in the pen. Introduced juveniles lost more of the interactions in which they were involved than did resident juveniles (Table 1: Chi square $=10.83$, d.f. $=1, \mathrm{P}<0.001$ ).

Introduced juveniles interacted with both adult and juvenile residents. Of the 401 interactions involving introduced hares, $345(86 \%)$ interactions were with adult residents, and $56(14 \%)$ were with resident juveniles. Introduced hares lost 312 of the 345 interactions $(90.4 \%$ ) with adult residents, and they lost 50 of the 56 interactions $(89.3 \%)$ with juvenile residents.

\section{Interactions among Free-Ranging Hares}

Approximately one-third of the wild hares under observation had been ear-tagged with plastic discs. Agonistic behaviour patterns were similar to those observed in the pens, i.e., they ranged from "ears up" through "chases" to "hits" (Graf, 1985), and approaches were initiated by both adults and juveniles. Seventy agonistic interactions involving juvenile hares were observed over a period of 62.5 hours (1.1 interactions per hour for all juveniles present) from 25 June to 20 August 1980 . Adult hares were dominant to juveniles in 30 of 36 interactions $(83.3 \%)$, and first litter juveniles were dominant to second litter juveniles in 17 of 22 interactions (77.3\%).

\section{DISCUSSION}

There was no evidence of nest building by female hares. Neither Severaid (1942) nor Grange (1932) observed nest building in penned $L$. americanus. They found that female hares dropped their litters almost anywhere in their pen, usually under some form of cover. Nursing was the major parental investment adult hares made after the leverets were born. Female hares made some weak attempts to protect their leverets from predators (grey jays), but the attempts never succeeded. Male snowshoe hares provided no parental care.

The combination of absence of nest building, precocial young and reduced suckling periods is quite different from that found in the closely related rabbits (Oryctolagus, Sylvilagus). The latter types dig nesting burrows or shallow holes and provide a fur and vegetative lining for their altrical young, as found in the swamp rabbit (Sorenson et al., 1972) and the European rabbit (Lockley, 1961). This difference in nest building is one of the main ecological differences between hares and rabbits. The lack of a nest in $L$. americanus is linked to other life history traits, such as precocial young that can run at 7 days old, reduced suckling time to avoid detection by predators and predator avoidance by running when the young are older.

The absence of a nest and other associated traits suggest that young hares have weak nest site attachment and they may disperse. Our introduction experiments were intended to mimic what happens when dispersing juveniles enter unknown areas. We compared two situations: (1) those juveniles trapped on an area from which all animals were repeatedly removed (this removal grid was part of a long-term experiment concerning the 10-year cycle; see Krebs et al., 1986), and (2) those trapped in non-removal areas. Myers and Krebs (1971) classified those animals trapped on a removal grid as dispersers, and Krebs (1986) considers such dispersers in snowshoe hares are those responding to limited resources (food, space) in their natal areas. Boutin et al. (1985) have argued that animals caught on removal grids are those exploring new areas and may not differ from hares in other non-removal situations. In our experiments, the hourly interaction rates of hares from removal grids with residents $(10)$ were the same as those between non-removal hares with residents (10), supporting the conclusion of Boutin $e t$ al. (1985). This suggests that all introduced juveniles were reacting to a new environment in a similar manner. It seems likely that the behaviour of the introduced animals was more characteristic of dispersers than of residents, since the introductions mimicked the situation normally facing a disperser.

Interactions between introduced and resident hares occurred over access to food, water, resting spots and right-of-way along pathways. All 30 of the introduced juveniles were involved in, and lost, agonistic interactions with residents. Both resident adults and resident juveniles interacted with the introduced juveniles, although the resident adults were involved much more than were the resident juveniles. Introduced juveniles interacted with resident hares at a higher rate than did resident juveniles and also lost more interactions than did resident juveniles. The results were consistent with the prediction that dispersing juveniles experience more aggression than do resident adult or juvenile hares. This result is consistent with smaller scale experiments in which introduced animals lost in interactions over limited food supplies (Sinclair, 1986). Therefore, it is possible that juvenile mortality (which is correlated with population density through the cycle) is produced in part by dispersal and aggression over limited resources.

The pen experiment could not be repeated with free-ranging hares, but an unmanipulated wild population was observed. The juvenile/adult agonistic interactions observed were similar to those found in the pens. We could not tell whether dispersers encountered higher levels of aggression than did non-dispersers in the wild, since we did not know the residential status of many of the hares.

Adult aggression toward non-resident juvenile European rabbits has been recorded in small indoor pens (Mykytowycz and Dudzinski, 1972), in large, outdoor enclosures (Mykytowycz, 1960; Lockley, 1961) and in wild populations (Southern, 1948; Mykytowycz and Gambale, 1965). Mykytowycz (1960) and Mykytowycz and Gambale (1965) also show that resident juveniles were aggressive toward dispersing non-resident juveniles.

Data from this pen experiment and wild hares suggest that weaned juveniles moving into an area already populated with resident hares are faced with higher rates of agonistic interaction than are juveniles already resident in the area. This increased aggression could lead to further dispersion by the non-resident 
juvenile or to increased stress (Christian and Davies, 1964), either of which may lower its chances of survival.

Field experiments should be performed to determine how effective aggression may be on limiting juvenile recruitment in snowshoe hares. Experiments could take the form of adding juveniles to manipulated and control populations, as in Boonstra (1978), or by monitoring natural recruitment to manipulated and control populations, as in Redfield et al. (1978). Boutin (1984) has conducted some of these experiments, with results consistent with the pen observations.

\section{ACKNOWLEDGEMENTS}

We would like to thank the Arctic Institute of North America and its staff for the opportunity to use its facilities at the Kluane Lake Research Station. Many people helped with the construction of enclosures, trapping, etc. We greatly appreciate their assistance. Special thanks go to Stan Boutin for his assistance throughout the project. Research costs were covered by a cooperative grant from the Natural Sciences and Engineering Research Council of Canada to C.J. Krebs, J.N.M. Smith and A.R.E. Sinclair (University of British Columbia) and grants from the Canadian National Sportsman's Fund and the Canadian Wildlife Service. R. Graf received personal support from a University of British Columbia graduate fellowship and two MacMillan Fraser fellowships. Finally, we would like to thank the two anonymous reviewers for their constructive comments.

\section{REFERENCES}

BOONSTRA, R. 1978. Effect of adult townsend voles (Microtus townsendii) on survival of young. Ecology 59:242-248.

BOUTIN, S.A. 1979. Spacing behavior of snowshoe hares in relation to their population dynamics. M.Sc. thesis, University of British Columbia, Vancouver, British Columbia, Canada.

1984. The effect of conspecifics on juvenile survival and recruitment of snowshoe hares. Journal of Animal Ecology 53:623-637.

BOUTIN, S., GILBERT, B.S., KREBS, C.J., SINCLAIR, A.R.E., and SMITH, J.N.M. 1985. The role of dispersal in the population dynamics of snowshoe hares. Canadian Journal of Zoology 63:106-115.

BROEKHUIZEN, S., and MAASKAMP, F. 1980. Behaviour of does and leverets of the European hare (Lepus europaeus) whilst nursing. Journal of Zoology, London 191:487-501.

CHITTY, D. 1960. Population processes in the vole and their relevance to general theory. Canadian Journal of Zoology 38:99-113.

CHRISTIAN, J.J., and DAVIES, D.E. 1964. Endocrines, behaviour, and populations. Science 146:1550-1560.
DOUGLAS, G.W. 1974. Montane zone vegetation of the Alsek River region, southwestern Yukon. Canadian Journal of Botany 52:2505-2532.

GRAF, R.P. 1981. Some aspects of snowshoe hare behavioural ecology. M.Sc. thesis, University of British Columbia, Vancouver, British Columbia, Canada. $132 \mathrm{p}$.

1985. Social organization of snowshoe hares. Canadian Journal of Zoology 63:468-474.

GRANGE, W.B. 1932. Observations on the snowshoe hare, Lepus americanus phaeonotus Allen. Journal of Mammalogy 13:1-19.

KEITH, L.B., and WINDBERG, L.A. 1978. A demographic analysis of the snowshoe hare cycle. Wildlife Monographs No. $58.70 \mathrm{p}$.

KREBS, C.J. 1986. Are lagomorphs similar to other small mammals in their population ecology? Mammal Review 16:187-194.

and MYERS, J.H. 1974. Population cycles in small animals. Advances in Ecological Research 8:268-389.

KREBS, C.J., GILBERT, B.S., BOUTIN, S., SINCLAIR, A.R.E., and SMITH, J.N.M. 1986. Population biology of snowshoe hares 1. Demography of food-supplemented populations in the southern Yukon, 1976-84. Journal of Animal Ecology 55:963-982.

LOCKLEY, R.M. 1961. Social structure and stress in the rabbit warren. Journal of Animal Ecology 30:385-423.

MYERS, J.H. , and KREBS, C.J. 1971. Genetic, behavioural, and reproductive attributes of dispersing field voles Microtus pennsylvanicus and Microtus ochrogaster. Ecological Monographs 41:53-78.

MYKYTOWYCZ, R. 1960. Social behaviour of an experimental colony of wild rabbits, Oryctolagus cuniculus (L.), III Second breeding season. Commonwealth Scientific Industrial Research Organization Wildlife Research 5:1-20. and DUDZINSKI, M.L. 1972. Aggressive and protective behaviour of adult rabbits, Oryctolagus cuniculus (L.), towards juveniles. Behaviour 43:97-120.

MYKYTOWYCZ, R., and GAMBALE, S. 1965. A study of the inter-warren activities and dispersal of wild rabbits, Oryctolagus cuniculus (L.), living in a 45-ac paddock. Commonwealth Scientific Industrial Research Organization Wildlife Research 10:111-123.

REDFIELD, J.A., TAITT, M.J., and KREBS, C.J. 1978. Experimental alterations of sex ratios in populations of Microtus oregoni, the creeping vole. Journal of Animal Ecology 47:55-69.

RONGSTAD, O.J., and TESTER, J.R. 1971. Behavioural and maternal relations of young snowshoe hares. Journal of Wildlife Management 35:338-346.

SEVERAID, J.H. 1942. The snowshoe hare: Its life history and artificial propagation. Augusta: Maine Departhent of Inland Fish and Game. 95 p.

SINCLAIR, A.R.E. 1986. Testing multi-factor causes of population limitation: An illustration using snowshoe hares. Oikos 47:360-364.

SORENSON, M.F., ROGERS, J.P., and BASKETT, T.S. 1972. Parental behaviour in swamp rabbits. Journal of Mammalogy 53:840-849.

SOUTHERN, H.N. 1948. Sexual and aggressive behaviour in the wild rabbit. Behaviour 1:173-193.

TRIVERS, R.L. 1972. Parental investment and sexual selection. In: Campbell, B., ed. Sexual selection and the descent of man 1871-1971. Chicago: Aldine Publication Company. 136-179. 